\title{
Compost Biofilters for Protection of Environmentally Sensitive Areas Receiving Roadway Runoff
}

\author{
Duncan McTaggart ${ }^{1}$, William R Trenouth ${ }^{1}$, Stephen Stajowski ${ }^{1}$, Hani Farghaly ${ }^{2} \&$ Bahram Gharabaghi $^{1}$ \\ ${ }^{1}$ School of Engineering, University of Guelph, Guelph, Ontario, Canada \\ ${ }^{2}$ Ontario Ministry of Transportation, 301 St. Paul Street, St. Catharines, Canada \\ Corresponding Author: Bahram Gharabaghi, School of Engineering, University of Guelph, Guelph, ON., N1G \\ 2W1, Canada. Tel: 1-519-824-4120. Ext: 58451. E-mail: bgharaba@uoguelph.ca
}

\author{
Received: May 26, 2018 \\ Accepted: June 6, 2018 \\ Online Published: July 17, 2018 \\ doi:10.5539/esr.v7n2p88 \\ URL: https://doi.org/10.5539/esr.v7n2p88
}

The research is financed by Natural Sciences and Engineering Research Council of Canada (NSERC).

\begin{abstract}
Runoff from roads is well recognized as containing a host of heavy metals that may degrade water quality. This awareness has driven a focus towards management strategies intended to attenuate the transport of heavy metals to nearby water bodies. Composted biomass has been shown to have the ability to retain common roadway runoff pollutants, leading to interest in its use as a filter material for the protection of environmentally sensitive areas. Compost biofilters can be constructed in a tubular geometry to intercept surface flow and can be amended with polymers for the targeted removal of specific pollutants. Addressing the need for validation of this concept under field conditions, commercially available tubular biofilters with three different polymeric amendments were studied to assess their efficiency in removing heavy metals and total suspended solids. The filters each contained a mixture of municipal compost and were installed in series as a treatment train adjacent to a busy section of highway 401 in southern Ontario, Canada. Untreated inflow concentrations of chromium, cadmium, copper and lead exceeded Ontario Provincial Water Quality Objectives (PWQO). The biofilter treatment train reduced chromium to below its PWQO, while copper remained above. Results demonstrate removal efficiencies for the treatment train ranging from $15.5 \%$ (nickel) to $93.6 \%$ (chromium). The low removal efficiency of nickel is attributed in part to its low inflow concentration. Each consecutive filter also reduced TSS concentrations, with an event mean removal efficiency of $50 \%$ for the treatment train as a whole.
\end{abstract}

Keywords: environmentally sensitive areas, roadway runoff, heavy metals, compost biofilters

\section{Introduction}

Runoff from roads has been implicated as a significant cause of freshwater impairment (Bartlett, Rochfort, Brown, \& Marsalek, 2012; Gazendam, Gharabaghi, McBean, Whiteley, \& Kostaschuk, 2009; Trenouth \& Gharabaghi, 2016). Hydrocarbons, chlorides, and heavy metals such as nickel, zinc, chromium, lead, and copper are characteristic of highway runoff (Hallberg, Renman, \& Lundbom, 2007; Mayer et al., 2011; Perera et al., 2010 \& 2013; Trenouth, Gharabaghi, \& Perera, 2015; Trenouth et al., 2018; Salek et al., 2018). Diffuse sources of pollutants on roadways include automobile deterioration, tailpipe exhaust, and slow leaks of vehicle fluids (Thomson, McBean, Mostrenko, \& Snodgrass, 1994). Road salt, which is heavily applied to roads in northern climates as a deicing agent, also contains trace quantities of heavy metals (Betts, Gharabaghi, \& McBean, 2014; Brown \& Peake, 2006; Kilgour, Gharabaghi, \& Perera, 2014; Perera, Gharabaghi, \& Noehammer, 2009). These pollutants accumulate on the road surface and are rapidly washed off during rain and snowmelt events, ending up in nearby soil, sediment, surface water, or groundwater.

Heavy metals are a concern due to their persistence in the environment and demonstrated toxicity at low concentrations (Dehghani, Moore, Vasiluk, \& Hale, 2017; Mayer et al., 2011; Trenouth \& Gharabaghi, 2015b; Trenouth et al., 2016). Metals found in highway runoff can elicit a range of lethal and sub-lethal effects on freshwater organisms, including organ damage, reduced energy, and growth impairment (Flemming \& Trevors, 1989; Sherwood, Rasmussen, Rowan, Brodeur, \& Hontela, 2000; Vinodhini \& Narayanan, 2008). Highway runoff concentrations of $\mathrm{Cu}, \mathrm{Zn}$, and $\mathrm{Pb}$ observed in the literature were synthesized by Trenouth and Gharabaghi (2015b), 
with all three metals noted to exceed $200 \mu \mathrm{g} / \mathrm{L}$. While these observations represent a worst-case scenario where direct highway runoff enters a watercourse with minimal dilution, there is nonetheless concern over chronic exposure for sensitive species. Sublethal effects have been shown to occur in third generation brook trout (Salvelinus fontinalis) exposed to total $\mathrm{Pb}$ concentrations below $119 \mu \mathrm{g} / \mathrm{L}$ (Holcombe, Benoit, Leonard, \& McKim, 1976), and dissolved $\mathrm{Cu}$ at $5 \mu \mathrm{g} / \mathrm{L}$ produced sublethal effects in salmonids (Flemming \& Trevors, 1989). In Canada, the province of Ontario has created a set of Provincial Water Quality Objectives (PWQOs) for ambient surface water concentrations of an extensive list of substances. Ontario's PWQOs are set at concentrations designed to be protective of all aquatic life over an indefinite exposure duration (Ministry of the Environment and Climate Change, 2018). Table 1 summarizes the PWQOs for metals relevant to highway runoff.

Table 1. Ontario Provincial Water Quality Objectives for selected contaminants (MOECC, 2018)

\begin{tabular}{lcl}
\hline Metal & PWQO $(\mu \mathrm{g} / \mathrm{L})$ & Notes \\
\hline Cobalt & 0.9 & \\
Cadmium & 0.1 & for water hardness as $\mathrm{CaCO}_{3}$ from $0-100 \mathrm{mg} / \mathrm{L}$ \\
Chromium (VI) & 1 & \\
Chromium (III) & 8.9 & \\
Copper & 5 & for water hardness as $\mathrm{CaCO}_{3}>20 \mathrm{mg} / \mathrm{L}$ \\
Lead & 3 & for water hardness as $\mathrm{CaCO}_{3}$ from $30-80 \mathrm{mg} / \mathrm{L}$ \\
Nickel & 25 & \\
Zinc & 200 & \\
\hline
\end{tabular}

The large and distributed spatial coverage of roads makes runoff quality management from these features challenging. Instead, runoff management efforts have focused largely on peak flow control and conveyance. For roads in rural areas, this is traditionally achieved using open ditches and grass swales. While some degree of pollutant removal is achieved using swales (e.g. through uptake by vegetation and sedimentation), greater protection of aquatic systems may be required in environmentally sensitive areas. To be feasible, roadway runoff treatment techniques must be effective across a range of pollutant types, easy to install and maintain, and be affordable. To this end, compost material has seen increased research and development over the last ten years as a material for the attenuation of pollutants in stormwater. Organic material is now frequently collected as a separate waste stream in many municipalities, leading to an abundant supply (Mustapha, 2013). Compost has been tested and used as a surface layer in bioretention facilities and in tubular biofilters to intercept surface flow in swales or depressions as a form of check dam (Paus, Morgan, Gulliver, \& Hozalski, 2014; Taleban et al., 2009).

Compost biofilters, known colloquially as filter socks, are constructed from partially decomposed organic matter housed within a tubular mesh made from plastic resin or environmentally degradable material. This creates a modular filter device that can be readily installed in customizable arrangements within pre-existing roadway drainage swales. Prior research on compost biofilters has focused mainly on the filtration of suspended sediments, while considerably less attention has been directed towards heavy metal removal. Nonetheless, research has indicated that such devices are capable of removing both particulate-bound and dissolved metals (Faucette et al., 2009; Finney, Gharabaghi, Mcbean, Rudra, \& Macmillan, 2010). Removal of the particulate fraction is achieved by: A) sedimentation caused by reduced flow velocities upstream from the check dam; and B) filtration of suspended sediment within the compost pore matrix (DeLay \& Gharabaghi, 2018; Liu, Yang, Yu, Lung, \& Gharabaghi, 2015). The removal of dissolved metal cations is achieved by adsorption and complexation with negatively charged polar functional groups present in organic compost material (Seelsaen, McLaughlan, Moore, \& Stuetz, 2007).

The heavy metal removal efficiency of compost biofilters has been tested in the laboratory and field, with results displaying varying degrees of performance. The removal efficiency of $\mathrm{Cu}$ and $\mathrm{Zn}$ was studied under laboratory conditions by Faucette et al. (2009) and was calculated to be 67 and 54\% respectively. In contrast, Finney et al. (2010) conducted a field-scale study adjacent to a busy highway in Southern Ontario, Canada, and found that over 21 sample events the mean $\mathrm{Cu}$ and $\mathrm{Zn}$ removal efficiency was 29 and 32\% respectively. This discrepancy is likely due to the inflow metal concentrations used by Faucette et al. (2009), which where more than two orders of magnitude larger than those of Finney et al. (2010). To provide added attenuation of pollutants, compost biofilters may be amended with other materials. For example, Filtrexx Canada Inc. offers compost biofilters that may be amended with additives for the enhanced removal of specific pollutant classes such as metals, hydrocarbons, and nutrients. These additives are typically anionic polymers such as polyacrylamide, similar to what is used in water 
and wastewater treatment facilities to enhance flocculation and adsorb cationic pollutants (Faucette et al., 2009). However, there has been little investigation into their efficacy as an additive to compost biofilters, particularly under field conditions. A primary objective of this study is to provide insight into the heavy metal removal efficiency of commercial compost biofilters containing an additive for targeted removal of heavy metals. A comparison is made to biofilters containing additives for targeted removal of other pollutant categories. Compost filters were installed in an open grassed swale serving a busy highway in southern Ontario, Canada, to provide realistic field conditions.

\section{Methods}

Field monitoring was conducted to test the metal removal efficiency of compost biofilters installed as a treatment train under field conditions. The treatment train consisted of a total of nine individual compost biofilters, partitioned into three equally-sized batteries comprised of three biofilters each. Approximately $30 \mathrm{~m}$ separated each battery of filters, and each biofilter within a battery was separated by $1.5 \mathrm{~m}$, for a total battery length of 3.9 $\mathrm{m}$. Filters were $30 \mathrm{~cm}$ in diameter and lined the bottom of the swale, with wood stakes used to fix them in position. Each battery of biofilters was assigned one of three different additives for additional removal of targeted pollutants. In order of position from upstream to downstream, these additives target the following pollutant classes: 1) hydrocarbons; 2) heavy metals; and 3) nitrogen compounds. The compost filters and the additives were supplied together, with the additive pre-mixed into the compost material. The general purpose of each amendment type is to provide flocculation and sorption for the targeted contaminant class as appropriate. The focus of this study is on the removal performance of an amendment for the removal of heavy metals.

The treatment train was installed along a $75 \mathrm{~m}$ length of dry swale adjacent to highway 401 in southern Ontario, Canada (570972 m E, $4811554 \mathrm{~m} \mathrm{~N}$; 17T, NAD83). The section of the drainage swale used in this study was separated from the highway with an impermeable berm to ensure that no highway runoff enters between filters. Although this section of highway is located in a rural area it is a major interprovincial transport corridor and has a mean annual traffic volume of 106,500 vehicles per day in this area (Ontario Ministry of Transportation, 2016). The monitored ditch drains the three lanes of eastbound traffic plus a paved shoulder, as well as a four-lane overpass. The combined area of roadway contributing to the monitored swale was estimated from the relationship between precipitation and discharge. A V-notch weir instrumented with a pressure transducer was placed at the upstream and downstream end of the monitored swale section. Discharge was monitored during the non-frozen season for 10 events in which discharge through the weir was generated (Figure 1). Precipitation data was sourced from an Environment and Climate Change Canada weather station located approximately $20 \mathrm{~km}$ to the west of the field site. The drainage area is estimated to be approximately $1776 \mathrm{~m}^{2}$ based on a highway width of $11.1 \mathrm{~m}$ ( 3 lanes + shoulder) and a length of contributing highway of approximately $160 \mathrm{~m}$.

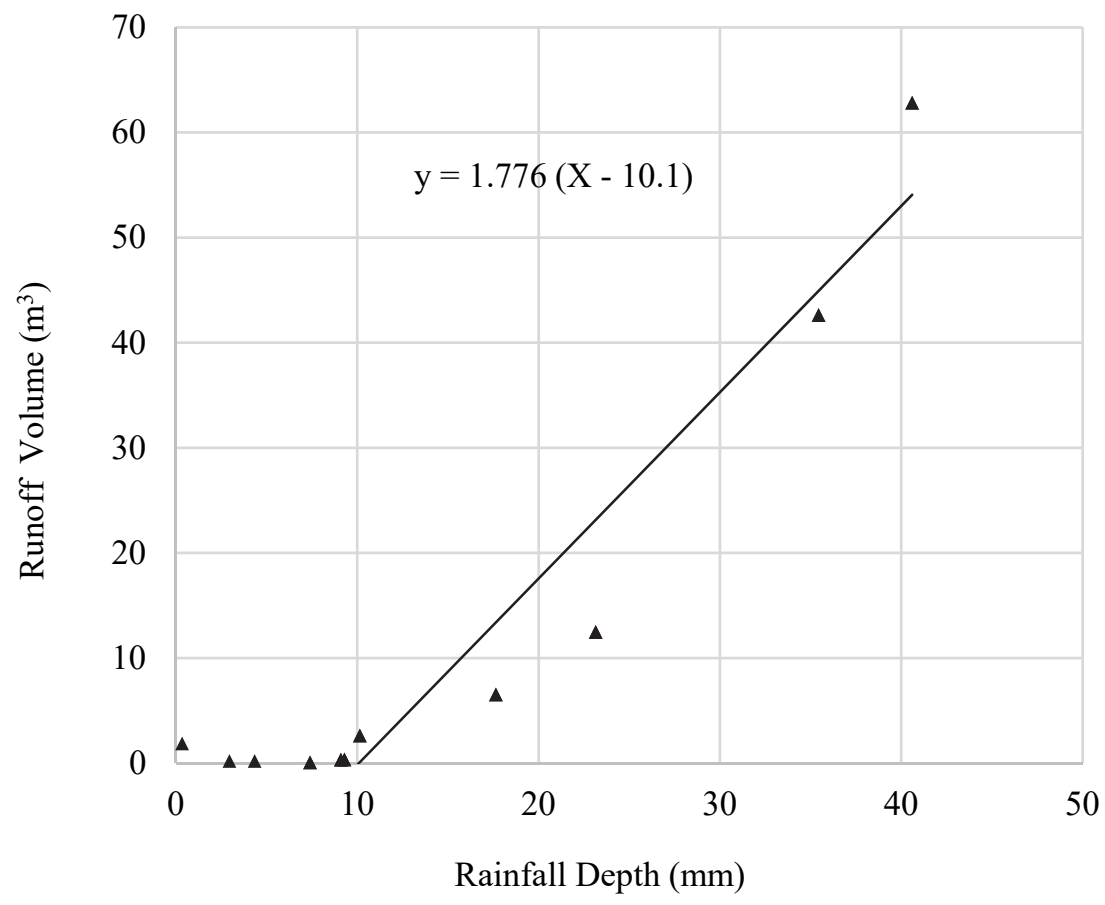


Figure 1. Monitored rainfall and runoff volume.

Water quality was measured with Teledyne ISCO autosamplers (model 6712), which were installed downstream of each filter battery. A fourth autosampler was installed immediately upstream from the first filter in the treatment train to monitor inflow water that had not passed through a biofilter. Monitoring was conducted over a two-year period beginning May 2013 and ending in August 2015 (Table 2). Samples were analyzed for a suite of heavy metals (total dissolved plus particulate) according to standard practices by a commercial laboratory, and TSS was analyzed at the University of Guelph School of Engineering. Removal efficiency for all analytes were calculated as follows:

$$
\text { Removal Efficiency }=\frac{C_{\text {in }}-C_{\text {out }}}{C_{\text {in }}} * 100 \%
$$

Where $C_{\text {in }}$ is the analyte concentration of untreated runoff $(\mu \mathrm{g} / \mathrm{L})$ and $\mathrm{C}_{\text {out }}$ is the analyte concentration after the biofilter treatment train $(\mu \mathrm{g} / \mathrm{L})$. Sample collection for TSS took place during the first summer that the filters were installed. The antecedent dry period prior to washoff has been shown to correlate positively with pollutant load, and is shown for each event in Table 2 (Finney et al., 2010). Heavy metals were monitored in 2015, after two years of exposure post-installation.

Table 2. Summary of TSS and metal monitoring event characteristics

\begin{tabular}{|c|c|c|c|c|c|c|}
\hline \multirow[b]{2}{*}{ Event date } & \multicolumn{3}{|c|}{ TSS Monitoring } & \multicolumn{3}{|c|}{ Heavy Metal Monitoring } \\
\hline & 4-July-13 & 7-July-13 & 2 -Aug-13 ${ }^{\mathrm{A}}$ & 05-Jun-15 & 12-Jun-15 & $15-J u n-15$ \\
\hline Months from installation & 1 & 1 & 2 & 25 & 25 & 25 \\
\hline Event precipitation & $12 \mathrm{~mm}$ & $8.7 \mathrm{~mm}$ & $15.3 \mathrm{~mm}$ & $17.1 \mathrm{~mm}$ & $12.6 \mathrm{~mm}$ & $9.9 \mathrm{~mm}$ \\
\hline Antecedent dry period & 5.2 days & 1.3 days & 1.5 days & 1.3 days & 3 days & 1 day \\
\hline
\end{tabular}

Note: ${ }^{\mathrm{A}}$ samples collected at every monitoring station; ${ }^{\mathrm{B}}$ Inflow concentration monitoring only

Samples of the material (compost and additive) within the biofilters were collected from each battery and analyzed for heavy metal content. Samples were collected from the upstream biofilter in each battery on 17-May-2015 and analyzed according to standard procedures by a commercial laboratory. This set of tests was performed to provide insight into the metal load captured by each battery of biofilters containing different additives.

\section{Results and Discussions}

\subsection{Total Suspended Solids}

Although dissolved phase metals pose a greater toxicological threat than their particulate-bound counterparts, the suspended phase should not be disregarded. Particulate phase metals may become mobilized as a consequence of changing $\mathrm{pH}$ and redox conditions over time and space (Miller \& Orbock Miller, 2007). Results show that the treatment train provided effective TSS reduction for untreated highway runoff. Though not shown here, the highest inflow concentration of TSS from six monitored events was $334 \mathrm{mg} / \mathrm{L}$. The Canadian Water Quality Guideline for TSS states that the maximum short-term increase in concentration should not exceed $25 \mathrm{mg} / \mathrm{L}$ above the baseflow, or "clear flow" concentration (Canadian Council of Ministers of the Environment, 2002). This event occurred after an antecedent dry period of 32 hours and a maximum rainfall intensity of $7 \mathrm{~mm} / \mathrm{hr}$. The mean peak inflow (untreated) TSS concentration from the three runoff events is $122 \mathrm{mg} / \mathrm{L}$. Since the first flush concept is intrinsically a short-duration event characteristic, it is difficult to capture its occurrence with the autosampler configuration that was employed. Therefore, peak TSS concentrations reported here are likely to be an underestimate of the true maximum.

The mean TSS removal efficiency for the treatment train as a whole is $50 \%$. Faucette, Sefton, Sadeghi, and Rowland (2008) assessed the TSS removal efficiency of a single $20.3 \mathrm{~cm}$ diameter compost filter receiving runoff from bare soil and reported removal efficiencies between $62 \%$ and $87 \%$. Their laboratory study yielded inflow TSS concentrations that were more than 90 times larger than those of the present study, and are representative of construction site or agricultural runoff, rather than road runoff. The higher removal efficiency of Faucette et al. (2008) is attributable to the larger hydraulic and sediment loading rates. A field-scale study conducted by Finney et al. (2010) showed that a compost biofilter (without any additives) reduced TSS in highway runoff by an average of $42 \%$. Although Finney et al. (2010) used only a single filter battery, it had a volume of $7.35 \mathrm{~m}^{3}$, whereas the 
combined volume of the treatment train used here was approximately $1.9 \mathrm{~m}^{3}$.

Each battery of filters used in this study is responsible for approximately the same proportion of TSS removal (Figure 2). Since the different additives are not expected to provide different levels of TSS removal this result is to be expected. Similar findings were reported by Taleban et al. (2009), where it was found that mean TSS removal efficiency improved by 26 percentage points when the number of $20 \mathrm{~cm}$ diameter compost filter socks filters was doubled from 5 to 10. These findings indicate that where high TSS concentrations are of concern, multiple filter socks can be used in close proximity as a treatment train to provide greater removal. The advisable number of filters will naturally depend on local water quality objectives and site-specific details.

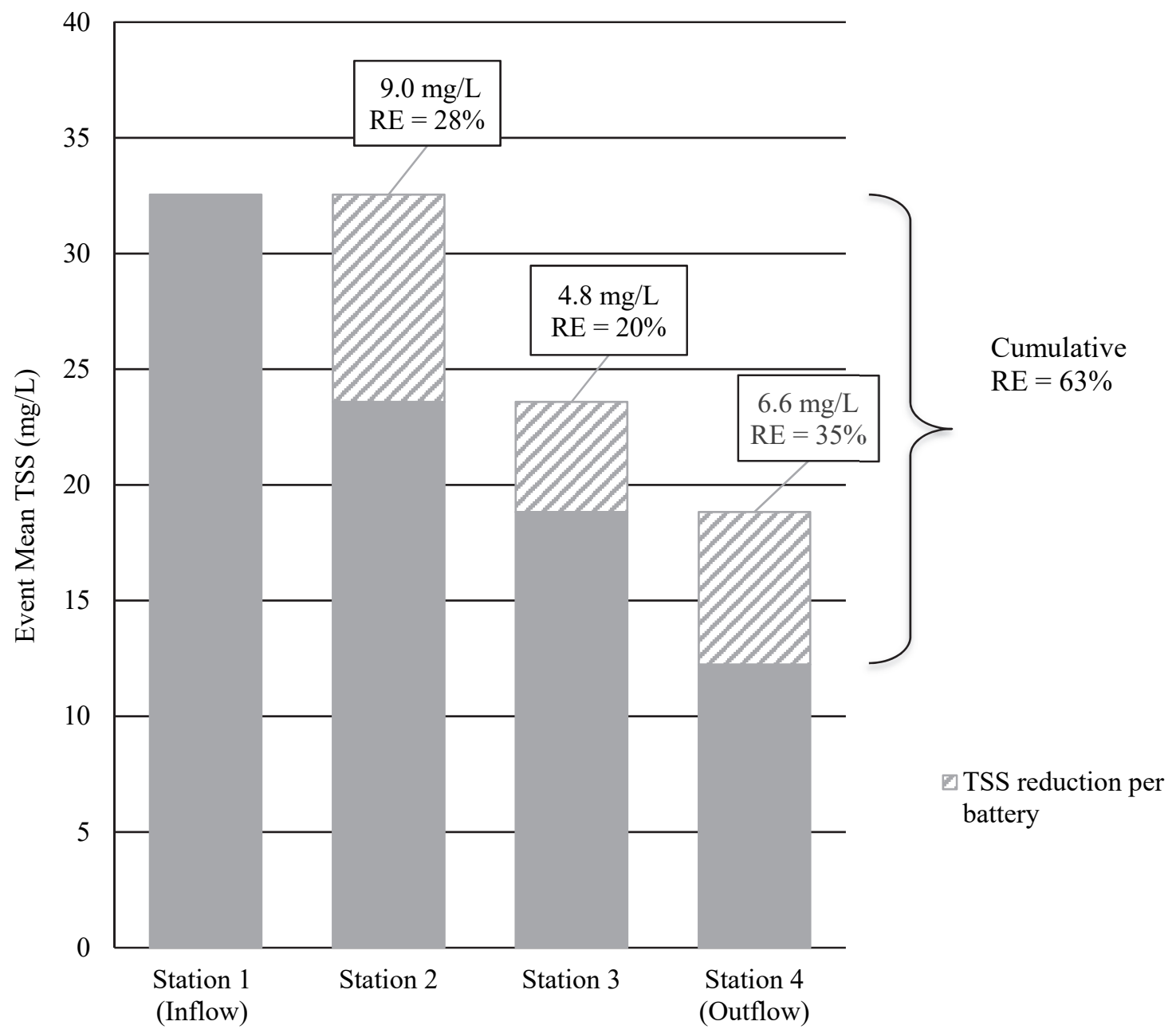

Figure 2. Event mean TSS concentrations for 2-Aug-2013 event measured both at the upstream and the downstream of each battery of filters to calculate TSS reduction per battery and the removal efficiency (RE).

Water travels sequentally from station 1 to station 4

\subsection{Heavy Metals}

Untreated inflow concentrations of all metals are congruent with those synthesized from the literature by Trenouth and Gharabaghi (2015b). Over the course of three events monitored, inflow concentrations of $\mathrm{Cr}, \mathrm{Cd}, \mathrm{Cu}$, and $\mathrm{Pb}$ exceeded their respective PWQO on one or more occasions. The biofilter treatment train showed competence in reducing heavy metals from highway runoff, though there is a high degree of variability between metals. During the rainfall event on 15-Jun-2015 all metals decreased in concentration after passing through the treatment train, with removal efficiencies ranging from $15.5 \%$ (Ni) to $93.6 \%$ (Cr) (Figure 3). Inflow concentrations of $\mathrm{Cd}$ and $\mathrm{Co}$ were below their respective detection limits of $0.09 \mu \mathrm{g} / \mathrm{L}$ and $0.5 \mu \mathrm{g} / \mathrm{L}$ for the $15-\mathrm{Jun}-2015$ event and therefore an assessment of removal efficiency was not made. Variability in removal efficiency is reflective of the different sorption affinities that a metal species has for contact surfaces (namely the compost material, polymer additives, 
native soil, and suspended sediment), as well as their inflow concentrations. The sorption affinity of a metal species largely dictates its speciation between dissolved and particulate fractions, as well as its tendency to be sorbed by negatively charged binding sites. The sorption capacity of various organic and inorganic compounds for divalent metals has been shown to follow the general trend of $\mathrm{Pb}>\mathrm{Cu}>\mathrm{Zn}>\mathrm{Cd}>\mathrm{Ni}$ (Ho, Porter, \& Mckay, 2002; Reddad, Gerente, Andres, Cloirec, \& Cloirec, 2002). Metals with a higher sorption capacity are expected to display a greater affinity for the compost and polymer, and will generally display greater removal efficiency. With respect to inflow concentration, the sorption of metals by compost can reasonably be assumed to follow first-order adsorption kinetics, and thus a high inflow concentration will yield a high removal efficiency (Trenouth \& Gharabaghi, 2015b) The relatively low nickel removal efficiency is attributed to a combination of its sorption capacity and inflow concentration, both of which are lower than other metal species studied here. However, since the untreated inflow concentration of $\mathrm{Ni}$ is well below its PWQO of $25 \mu \mathrm{g} / \mathrm{L}$, the low removal efficiency is not a significant concern (Figure 3).

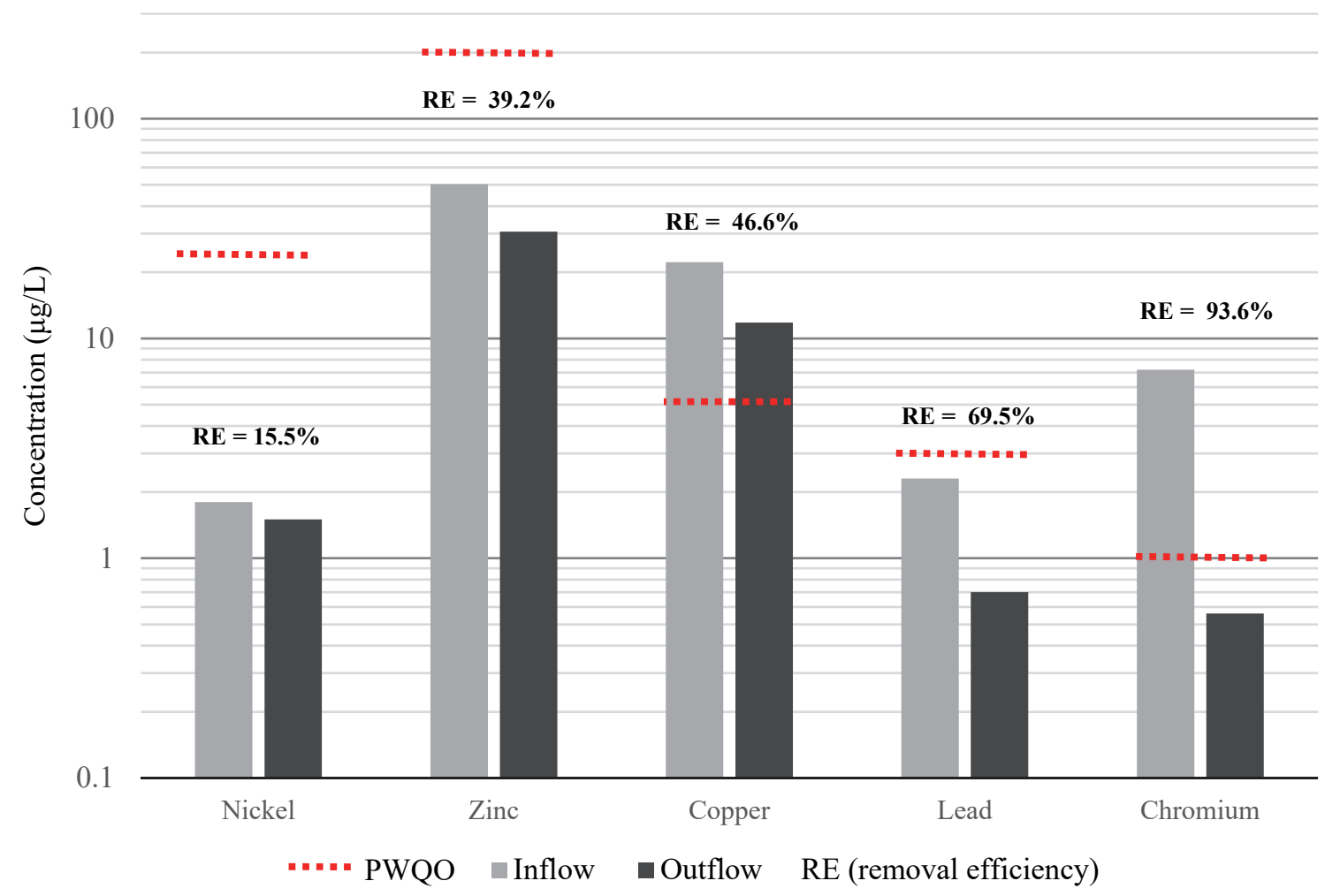

Figure 3. Comparison of inflow and outflow metal concentrations from the biofilter treatment train. Hyphenated red lines represent the respective Provincial Water Quality Objective for each metal species

Chromium (reported as $\mathrm{Cr} 3+$ and $\mathrm{Cr} 6+$ combined) was removed with the highest efficiency. Cations with larger valence states generally have a higher affinity for adsorption than those with smaller valence states and will outcompete for available binding sites (Miller \& Orbock Miller, 2007). As a result, the cobine $\mathrm{Cr}$ species demonstrated the highest removal efficiency (93\%) and were reduced to below the PWQO after passing the three batteries of biofilters. On the other hand, $\mathrm{Cu}$ remains $6.8 \mu \mathrm{g} / \mathrm{L}$ above its PWQO. The maximum inflow concentration observed for $\mathrm{Pb}$ is $45.2 \mu \mathrm{g} / \mathrm{L}$ on 12-June-2015, and when its removal efficiency from the 15-June2015 event is applied it would also remain above the PWQO. This is a precautionary extrapolation, since it doesn't factor in that first-order kinetics will yield a larger removal efficiency when the initial concentration is increased. In practice, the configuration (number of biofilters and size) should be chosen to meet the minimum desired water quality objective. In this case, additional filtration would be required to achieve the PWQO for $\mathrm{Cu}$. When analyzing the discharge data for the inflow and outflow weirs, it was noted that a considerable volume of water was lost between gauge stations. This loss is attributed to infiltration, which was likely enhanced by the nine tubular biofilters acting to increase the residence time of water flowing within the swale channel. This suggests that a grass swale with either a check-dam(s) or a high dynamic infiltration rate may serve as an appreciable repository for 
pollutants. Indeed, the pollutant removal performance of grass highway drainage swales has been previously evaluated, with marked improvements being noted for TSS and metals (Barrett, Walsh, Malina Jr., \& Charbeneau, 1998; Stagge, Davis, Jamil, \& Kim, 2012).

Heavy metal sampling was conducted two years after installation, which indicates that the attenuation benefits of the biofilters had not been exhausted. Research by Finney et al. (2010) estimates that compost biofilters may have an effective TSS treatment lifespan of more than ten years. However, the exhaustion of metal removal capacity in municipal compost has not been evaluated under conditions representative of highway runoff. Removal performance found in this study is generally comparable to the limited knowledgebase for biofilters receiving real or synthetic road runoff. Finney et al. (2010) found that average removal efficiencies of a compost biofilter ranged between zero and $63 \%$ for both $\mathrm{Cu}$ and $\mathrm{Zn}$. As this study was conducted under similar traffic volume and environmental conditions it provides effective validation of biofilter performance. Dissolved metals removal from synthetic runoff was studied in a set of column tests by Lim, Lim, Hu, Ziegler, and Ong, (2015). Their research found that the compost column treatment removed dissolved $\mathrm{Zn}, \mathrm{Cd}$, and $\mathrm{Pb}$ at rates greater than $98 \%$, and $\mathrm{Cu}$ removal efficiency measured 73.6\%. However, the inflow concentrations used by Lim et al. (2015) were higher than those found in untreated runoff in this study. As well, Lim et al. (2015) used fresh treatment media, whereas metal removal efficiency was measured after two years of exposure in this study.

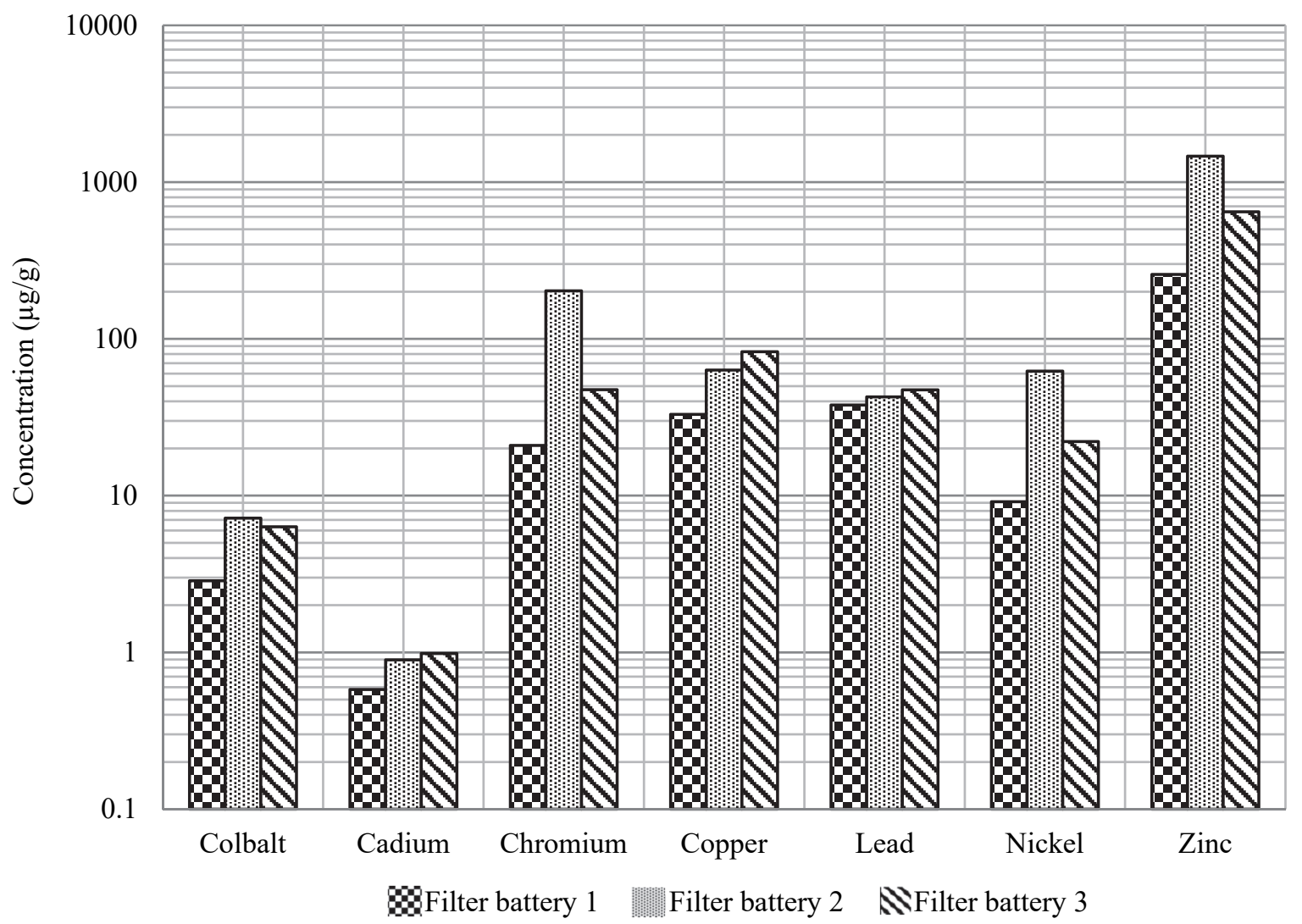

Figure 4. Heavy metal content within the biofilter material

Analysis of the metal content within the filter material provides insight to the different sorption rates between the three biofilter batteries, each of which contained a different amendment. Concentrations of $\mathrm{Co}, \mathrm{Cr}, \mathrm{Ni}$, and $\mathrm{Zn}$ were highest in the second battery of biofilters, which contained the additive for targeted removal of metals (Figure 4). In particular, the second battery of filters had substantially higher concentrations of $\mathrm{Zn}$ and Cr. The first battery in the treatment train, which contained the additive for targeted hydrocarbon removal, had the lowest concentrations of all metals. Intermediate between these is the third battery in the treatment train, which contained the additive for removal of nitrogen compounds. This third filter battery had the highest concentrations of $\mathrm{Cu}$ and $\mathrm{Pb}$. Although the experimental setup used herein does not allow for a direct side-by-side comparison, these findings indicate that the metal additive provides greater sorption capacity for some metals than the same biofilter 
configurations which do not contain the additive. Were there no difference between the additives it would be expected that filter battery in the treatment train would have the highest metal content, due to the greatest concentration exposure and first-order kinetics. Since $\mathrm{Cu}$ remained above its PWQO after exiting the treatment train, the observation that concentrations of $\mathrm{Cu}$ were approximately $20 \mu \mathrm{g} / \mathrm{g}$ higher in third biofilter battery is of note. The additive for nitrogen removal should be further investigated for its ability to retain $\mathrm{Cu}$. Faucette et al. (2009) studied the performance of compost biofilters with and without the metal flocculation additive and found that removal efficiency for all metals in dissolved phase improved marginally when the additive was included. Their laboratory study showed that improvement in dissolved metal removal efficiency for the metal additive treatment ranged between $2(\mathrm{Cu})$ and $12(\mathrm{Cr})$ percentage points. Compared to the control, there was little to no difference in particulate metal removal when the metal additive was present.

The annual heavy metal load for this region of highway 401 was estimated using an ANN (artificial neural networks) model developed by Trenouth and Gharabaghi (2016). ANNs loosely resemble the pattern-recognition framework of the human brain and are an alternative prediction technique to traditional statistically-based models such as multiple regression (ASCE Task Committee, 2000). ANNs are able to extract complex, non-linear relationships and have demonstrated strong performance in their application to environmental phenomenon (Atieh, Mehltretter, Gharabaghi, \& Rudra, 2015; Trenouth \& Gharabaghi, 2015a). The model developed by Trenouth and Gharabaghi (2016) used a global data set consisting of more than 900 discrete storm events to predict the mean daily unit area load $\left(\mu \mathrm{g} / \mathrm{m}^{2} * \mathrm{~d}\right)$ of pollutants on a road surface, and is based on the following input parameters:

- $\quad$ Rainfall depth (mm)

- Rainfall intensity $(\mathrm{mm} / \mathrm{hr})$

- Average annual daily traffic (vehicles/day)

- Antecedent dry period (hours)

For all inputs, the log-transformed mean and standard deviation was used, giving a total of eight input variables. The modelled mean daily unit application rate of select metals for this region of highway 401 are shown in Table 3. The mean daily unit application rate was multiplied by a drainage area of $1776 \mathrm{~m}^{2}$ to obtain a prediction of the average annual metal load for a drainage area of this size (Table 3). These values represent the estimated annual metal load received by the treatment train, less an unknown portion to infiltration. When sizing a biofilter for treatment of road runoff, this methodology can be used in lieu of metal monitoring to estimate the mean daily unit application rate, and the average annual load.

Table 3. Predicted metal load in highway runoff for a $1776 \mathrm{~m}^{2}$ drainage area

\begin{tabular}{lcc}
\hline \multicolumn{1}{c}{ Metal } & $\begin{array}{c}\text { Mean daily unit application rate } \\
\left(\mu \mathrm{g} / \mathrm{m}^{2} * \text { day }\right)\end{array}$ & $\begin{array}{c}\text { Average Annual Load } \\
(\mathrm{g})\end{array}$ \\
\hline Copper & 4.5 & 2.9 \\
Zinc & 80.2 & 52.0 \\
Chromium & 4.11 & 2.7 \\
Lead & 43.2 & 28.0 \\
\hline
\end{tabular}

Pollutant concentrations in road runoff are often highest during the winter and spring seasons (Hallberg et al., 2007). This has been attributed to road salt, which contains trace quantities of metals and accelerates corrosion of vehicles and infrastructure, as well as the degradation of metal snowplow blades coming in contact with the road surface. Bäckström, Nilsson, Håkansson, Allard, and Karlsson (2003) found that total metals in highway runoff at two sites in France increased in the winter by an average of $488.5 \%(\mathrm{Cd}), 873.5 \%(\mathrm{Co}), 393.5 \%(\mathrm{Cu}), 80 \%(\mathrm{Zn})$, $147.5 \%(\mathrm{~Pb})$. Hallberg et al. (2007) found that the dissolved fraction of $\mathrm{Cd}, \mathrm{Co}, \mathrm{Cr}$ and $\mathrm{Ni}$ was significantly higher $(p<0.01)$ in the winter than in the summer. The average seasonal increases during the winter were $127.4 \%(\mathrm{Cd})$, $75.9 \%(\mathrm{Cr}), 174.8 \%(\mathrm{Co})$, and $38.3 \%(\mathrm{Ni})$. Furthermore, it has been shown that the $\mathrm{pH}$ of snowmelt may be less than that of summer precipitation (Jeffries, Cox, \& Dillon, 1979), which could lead to the desorption of metals from compost biofilters. On top of this, $\mathrm{NaCl}$ from winter deicing operations has been shown to increase metal mobility in roadside soils (Norrström, 2005). The confluence of these phenomena could reasonably be expected to result in larger metal loads passing through the treatment train during the winter and spring than what has been presented here. However, the performance of compost biofilters under winter and early spring conditions has not been studied directly and this is an avenue in which research is required. 
While it's ostensible that compost biofilters provide TSS and metals removal rates that can enhance the performance of grass swales, the optimal deployment configuration remains less certain. The use of tubular compost biofilters to protect environmentally sensitive areas should consider the outflow water quality objective as well as the biofilter arrangement that will minimize the effort of installation and maintenance. The volume of biofilter material required to meet water quality objectives can be estimated based on the contributing drainage area and the pollutant removal capacity of the biofilter(s). To avoid overtopping during peak flow, a method to determine the minimum vertical height of a biofilter arrangement has been developed by Finney et al. (2011). A more rigorous determination of the minimum outflow water quality would consider dilution with receiving water, as well as a survey of sensitive species found therein.

\section{Conclusions}

Given the wide spatial distribution of roads and their associated contribution to pollutant loading, robust runoff water quality management for environmentally sensitive areas requires the use of affordable treatment systems with demonstrated performance. Summer runoff from a heavily trafficked highway in southern Ontario, Canada was found to contain elevated concentrations of heavy metals and suspended solids during the period of testing. This study has demonstrated that TSS reductions are achieved in nearly equal proportions by each of the three biofilter batteries in the treatment train studied. This suggests that greater filtration of suspended sediment can be achieved by increasing the volume of compost that comes in contact with highway runoff. The nine biofilter treatment train has shown to be effective at attenuating heavy metals over multiple years of exposure to real-world conditions. After passing the treatment train $\mathrm{Cr}$ was reduced to below its $\mathrm{PWQO}$, however $\mathrm{Cu}$ remained above its PWQO. This underscores the need to consider a range of heavy metals when designing a biofilter treatment strategy, as removal efficiencies and loading will vary considerably. Recognizing the expense required to characterize the heavy metal load at multiple locations, the artificial neural network model of Trenouth and Gharabaghi (2016) can be applied to estimate the mean daily unit application rate. Testing of the metal content within the filter material has provided evidence to suggest that a flocculation agent for added metal removal improves performance. The battery of filters containing the additive that targets heavy metals had the highest concentrations of $\mathrm{Co}, \mathrm{Cr}, \mathrm{Ni}$, an $\mathrm{Zn}$. It was found that the third battery of biofilters, which contained an additive for targeted removal of nitrogen compounds, contained the highest concentrations of $\mathrm{Cd}, \mathrm{Cu}$, and $\mathrm{Pb}$. These findings should be further assessed with a side-by-side comparison whereby all amendments receive an equivalent metal load.

\section{Acknowledgments}

The authors would like to thank the Ontario Ministry of Transportation for financial and in-kind support, and Filtrexx Canada Inc. for supplying the compost biofilters and amendments used in the study. Mention of trade or product names used herein does not constitute endorsement by the authors or their affiliated institutions.

\section{References}

Atieh, M., Mehltretter, S. L., Gharabaghi, B., \& Rudra, R. (2015). Integrative neural networks model for prediction of sediment rating curve parameters for ungauged basins. Journal of Hydrology, 531, 1095-1107. https://doi.org/10.1016/j.jhydrol.2015.11.008

Bäckström, M., Nilsson, U., Håkansson, K., Allard, B., \& Karlsson, S. (2003). Speciation of heavy metals in road runoff and roadside total deposition. Water, Air, and Soil Pollution, 147(1-4), 343-366. https://doi.org/10.1023/A:1024545916834

Barrett, M., Walsh, P., Malina Jr., J., \& Charbeneau, R. (1998). Performance of vegetative controls for treating highway runoff. Journal of Environmental Engineering, 11(November), 1121-1128. https://doi.org/10.1061/(ASCE)0733-9372(1998)124:11(1121)

Bartlett, A. J., Rochfort, Q., Brown, L. R., \& Marsalek, J. (2012). Causes of toxicity to Hyalella azteca in a stormwater management facility receiving highway runoff and snowmelt. Part I: Polycyclic aromatic hydrocarbons and metals. Science of the Total Environment, 414, 227-237. https://doi.org/doi:10.1016/j.scitotenv.2011.11.041

Betts, A. R., Gharabaghi, B., \& McBean, E. A. (2014). Salt vulnerability assessment methodology for urban streams. Journal of Hydrology, 517, 877-888. https://doi.org/10.1016/j.jhydrol.2014.06.005

Brown, J. N., \& Peake, B. M. (2006). Sources of heavy metals and polycyclic aromatic hydrocarbons in urban stormwater runoff. Science of the Total Environment, 359(1-3), 145-155. https://doi.org/10.1016/j.foreco.2006.01.031

Canadian Council of Ministers of the Environment. (2002). Canadian water quality guidelines for the protection 
of aquatic life: Total particulate matter. In: Canadian environmental quality guidelines, 1999, Canadian Council of Ministers of the Environment, Winnipeg. Retrieved from http://ceqg-rcqe.ccme.ca/ download/en/217

Dehghani, S., Moore, F., Vasiluk, L., \& Hale, B. A. (2017). The influence of physicochemical parameters on bioaccessibility-adjusted hazard quotients for copper, lead and zinc in different grain size fractions of urban street dusts and soils. Environmental Geochemistry and Health, 1-20. https://doi.org/10.1007/s10653-0179994-6

DeLay, E., \& Gharabaghi, B. (2018). A review of low-grade weirs as an agri-environmental best management practice in the Elginfield Municipal Drain watershed, Ontario, Canada. Journal of Soil and Water Conservation, 73(2), 42A-48A. https://doi.org/10.2489/jswc.73.2.42A

Faucette, L. B., Cardoso-Gendreau, F. A., Codling, E., Sadeghi, A. M., Pachepsky, Y. A., \& Shelton, D. R. (2009). Storm Water Pollutant Removal Performance of Compost Filter Socks. Journal of Environmental Quality, 38(3), 1233-9. https://doi.org/10.2134/jeq2008.0306

Faucette, L. B., Sefton, K. A., Sadeghi, A. M., \& Rowland, R. A. (2008). Sediment and phosphorus removal from simulated storm runoff with compost filter socks and silt fence. Journal of Soil and Water Conservation, 63(4), 257-264. https://doi.org/10.2489/63.4.257

Finney, K., Gharabaghi, B., Mcbean, E., Rudra, R., \& Macmillan, G. (2010). Compost Biofilters For Highway Stormwater Runoff Treatment. Water Quality Research Journal of Canada, 45(4), 391-402. https://doi.org/10.2166/wqrj.2010.039

Gazendam, E., Gharabaghi, B., McBean, E., Whiteley, H., \& Kostaschuk, R. (2009). Ranking of waterways susceptible to adverse stormwater effects. Canadian Water Resources Journal, 34(3), 205-228. https://doi.org/10.4296/cwrj3403205

Hallberg, M., Renman, G., \& Lundbom, T. (2007). Seasonal variations of ten metals in highway runoff and their partition between dissolved and particulate matter. Water, Air, and Soil Pollution, 181(1-4), 183-191. https://doi.org/10.1007/s11270-006-9289-5

Ho, Y. S., Porter, J. F., \& Mckay, G. (2002). Equilibrium isotherm studies for the sorption of divalent metal ions onto peat: copper, nickel and lead single component systems. Water, Air, \& Soil Pollution, 141(1-4), 1-33. https://doi.org/10.1023/A:1021304828010

Jeffries, D. S., Cox, C. M., \& Dillon, P. J. (1979). Depression of pH in Lakes and Streams in Central Ontario During Snowmelt. Journal of the Fisheries Research Board of Canada, 36(6), 640-646. https://doi.org/10.1139/f79-093

Kilgour, B. W., Gharabaghi, B., \& Perera, N. (2014). Ecological benefit of the road salt code of practice. Water Quality Research Journal of Canada, 49(1), 43-52. https://doi.org/10.2166/wqrjc.2013.129

Lim, H. S., Lim, W., Hu, J. Y., Ziegler, A., \& Ong, S. L. (2015). Comparison of filter media materials for heavy metal removal from urban stormwater runoff using biofiltration systems. Journal of Environmental Management, 147, 24-33. https://doi.org/10.1016/j.jenvman.2014.04.042

Liu, Y., Yang, W., Yu, Z., Lung, I., \& Gharabaghi, B. (2015). Estimating Sediment Yield from Upland and Channel Erosion at A Watershed Scale Using SWAT. Water Resources Management, 29(5), 1399-1412. https://doi.org/10.1007/s11269-014-0729-5

Mayer, T., Rochfort, Q., Marsalek, J., Parrott, J., Servos, M., Baker, M., ... Scott, I. (2011). Environmental characterization of surface runoff from three highway sites in Southern Ontario, Canada: 2. Toxicology. Water Quality Research Journal of Canada, 46(2), 121-136. https://doi.org/10.2166/wqrjc.2011.036

Miller, J., \& Orbock Miller, S. (2007). Contaminated rivers: a geomorphological-geochemical approach to site assessment and remediation. Dordrecht, The Netherlands: Springer.

Ministry of the Environment and Climate Change. (2018). Water Management Policies Guidelines Provincial Water Quality Objectives of the Ministry of Environment and Energy. Retrieved from https://www.ontario.ca/page/water-management-policies-guidelines-provincial-water-qualityobjectives\#section-2

Norrström, A. C. (2005). Metal mobility by de-icing salt from an infiltration trench for highway runoff. Applied Geochemistry, 20(10), 1907-1919. https://doi.org/10.1016/j.apgeochem.2005.06.002

Ontario Ministry of Transportation. (2016). Ontario Provincial Highways Traffic Volumes on Demand. Retrieved 
from http://www.raqsb.mto.gov.on.ca/techpubs/Traffic Volumes.nsf/tvweb

Paus, K. H., Morgan, J., Gulliver, J. S., \& Hozalski, R. M. (2014). Effects of Bioretention Media Compost Volume Fraction on Toxic Metals Removal, Hydraulic Conductivity, and Phosphorous Release. Journal of Environmental Engineering, 140(10), 4014033. https://doi.org/10.1061/(ASCE)EE.1943-7870.0000846

Perera, N., Gharabaghi, B., \& Noehammer, P. (2009). Stream chloride monitoring program of city of Toronto: Implications of road salt application. Water Quality Research Journal of Canada, 44(2), 132-140. https://doi.org/10.2166/wqrj.2010.044

Perera, N., Gharabaghi, B., \& Howard, K. (2013). Groundwater Chloride Response in the Highland Creek Watershed Due to Road Salt Application: A Re-assessment after 20 Years. Journal of Hydrology, 479, 159168 .

Perera, N., Gharabaghi, B., Noehammer, P., \& Kilgour, B. (2010). Road Salt Application in Highland Creek Watershed, Toronto, Ontario. Water Qual. Res. J. of Can., 45(4), 451 - 461.

Reddad, Z., Gerente, C., Andres, Y., Cloirec, P. Le, \& Cloirec, P. L. E. (2002). Adsorption of Several Metal Ions onto a Low-Cost Biosorbent: Kinetic and Equilibrium Studies Adsorption of Several Metal Ions onto a LowCost Biosorbent : Kinetic and Equilibrium Studies. Environmental Science \& Technology, 36(9), 2067-2073. https://doi.org/10.1021/es0102989

Salek, M., Levison, J., Parker, B., \& Gharabaghi, B. (2018). CAD-DRASTIC: chloride application density combined with DRASTIC for assessing groundwater vulnerability to road salt application. Hydrogeology Journal, 1-15, https://doi.org/10.1007/s10040-018-1801-7

Stagge, J. H., Davis, A. P., Jamil, E., \& Kim, H. (2012). Performance of grass swales for improving water quality from highway runoff. Water Research, 46(20), 6731-6742. https://doi.org/10.1016/j.watres.2012.02.037

Taleban, V., Finney, K., Gharabaghi, B., McBean, E., Rudra, R., \& van Seters, T. (2009). Effectiveness of compost biofilters in removal of sediments from construction site runoff. Water Quality Research Journal of Canada, 44(1), 71-80. https://doi.org/10.2166/wqrj.2009.008

Trenouth, W. R., Gharabaghi, B., \& Farghaly, H. (2018). Enhanced roadside drainage system for environmentally sensitive areas. Science of The Total Environment, 610, 613-622.

Trenouth, W. R., \& Gharabaghi, B. (2016). Highway runoff quality models for the protection of environmentally sensitive areas. Journal of Hydrology, 542, 143-155.

Trenouth, W. R., \& Gharabaghi, B. (2015a). Event-based design tool for construction site erosion and sediment controls. Journal of Hydrology, 528, 790-795. https://doi.org/10.1016/j.jhydrol.2015.06.054

Trenouth, W. R., \& Gharabaghi, B. (2015b). Soil amendments for heavy metals removal from stormwater runoff discharging to environmentally sensitive areas. Journal of Hydrology, 529, 1478-1487. https://doi.org/10.1016/j.jhydrol.2015.08.034

Trenouth, W. R., \& Gharabaghi, B. (2016). Highway runoff quality models for the protection of environmentally sensitive areas. Journal of Hydrology, 542, 143-155. https://doi.org/10.1016/j.jhydrol.2016.08.058

Trenouth, W. R., Gharabaghi, B., \& Perera, N. (2015). Road salt application planning tool for winter de-icing operations. Journal of Hydrology, 524, 401-410. https://doi.org/10.1016/j.jhydrol.2015.03.004

\section{Copyrights}

Copyright for this article is retained by the author(s), with first publication rights granted to the journal.

This is an open-access article distributed under the terms and conditions of the Creative Commons Attribution license (http://creativecommons.org/licenses/by/4.0/). 